\title{
Decision Making Power in Domestic Sphere: Participation of Professional Indian Women in Kuala Lumpur and Selangor
}

\section{Yuvashini A/P Salvamani, Zuraini binti Jamil @ Osman}

To Link this Article: http://dx.doi.org/10.6007/IJARBSS/v11-i4/8838

DOI:10.6007/IJARBSS/v11-i4/8838

Received: 06 February 2021, Revised: 11 March 2021, Accepted: 28 March 2021

Published Online: 24 April 2021

In-Text Citation: (Salvamani \& Osman, 2021)

To Cite this Article: Salvamani, Y. A., \& Osman, Z. binti J. @. (2021). Decision Making Power in Domestic

Sphere: Participation of Professional Indian Women in Kuala Lumpur and Selangor. International Journal of Academic Research in Business and Social Sciences, 11(4), 741-749.

Copyright: (c) 2021 The Author(s)

Published by Human Resource Management Academic Research Society (www.hrmars.com)

This article is published under the Creative Commons Attribution (CC BY 4.0) license. Anyone may reproduce, distribute, translate and create derivative works of this article (for both commercial and non-commercial purposes), subject to full attribution to the original publication and authors. The full terms of this license may be seen at: http://creativecommons.org/licences/by/4.0/legalcode

Vol. 11, No. 4, 2021, Pg. 741 - 749

Full Terms \& Conditions of access and use can be found at http://hrmars.com/index.php/pages/detail/publication-ethics 


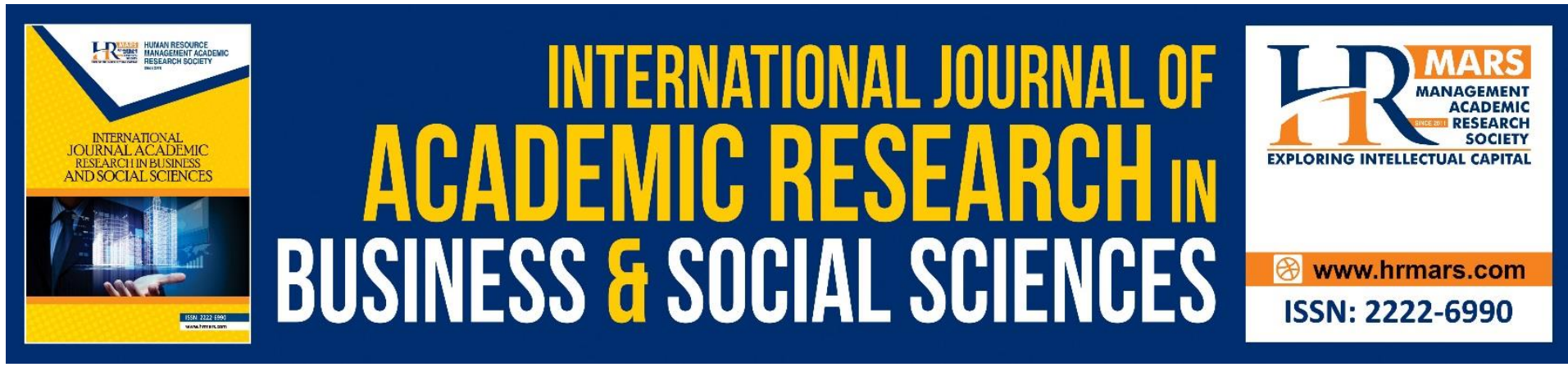

\title{
Decision Making Power in Domestic Sphere: Participation of Professional Indian Women in Kuala Lumpur and Selangor
}

\author{
Yuvashini A/P Salvamani \\ Faculty of Human Sciences, Universiti Pendidikan Sultan Idris, Centre for Foundation Studies, \\ Universiti Tunku Abdul Rahman \\ Email: yuva_girl90@yahoo.com.my
}

Zuraini binti Jamil @ Osman

Faculty of Human Sciences, Universiti Pendidikan Sultan Idris

Email: zuerjami@fsk.upsi.edu.my

\begin{abstract}
In most of the societies, the decision making power of women is limited due to gender perspectives and cultural practices. Similarly in Indian society, patriarchy ideology is very common in which men are the main breadwinners and decision-makers of the family but this belief is gradually changing. Thus, this study aims to explore the participation of professional Indian women in the decision making power in the family on the aspect of household matters. Fifteen Indian women, who work in different professional sectors and live in Kuala Lumpur and the Selangor area, were selected for this study. A qualitative approach using one to one in-depth interview method was used to gather the primary data. The findings show that majority of the husbands are sharing the household chores equally with their wife but there are still some men who do not provide any assistance in doing house works. Moreover, women have freedom to decide on basic things but there are differences in practice for men and women in terms of outing planning with friends. This study also revealed that the participation of Indian women in the decision-making in their family have increased in terms of financial aspects and children affairs.
\end{abstract}

Keywords: Professional Indian Women, Decision-Making Power, Family, Domestic Sphere, Equal Participation

\section{Introduction}

Women play an important role in the welfare of the family in a developing country like Malaysia. The participation of women in decision-making power has been noticed as one of the main factors that might influence the well-being of the family (Sultana, 2011; Neeru, Muzamil, Farhat and Iffat, 2014). Women often face a double challenge in their efforts to gain a degree of authority that will permit independent decision-making. This is because they need to overcome family opposition and they have to deal with social constraints. Independent 
women in highly patriarchal societies like the Indian society are often subject to strong patriarchal controls which make them unable to fully implement their preferences in ways that benefit their family (Jackson, 2010).

The common practice of men being the primary breadwinner of the family and women confined in domestic work have been changed because women are taking up professional roles outside their homes. Thus, it has been helpful for Indian women to realize their capabilities and potential, have a broader view of the outside world as well as able to find new path in the lives (Chouhan, Choundhary and Swarnakar, 2016). In addition, previous study states that education and financial independence of a woman increase the ability of decision-making compared to uneducated women. This is because education attainment helps to shape their way of thinking, behaviour and communication skills in an effective way to make decision. Furthermore, economic independence enhances the exposure of Indian working women which enable them to make a rational decision (Namdeo, 2017). Thus, it can be highlighted that education and economic independence are two important indicators that can increase the participation women in the decision-making process.

Therefore, I want to explore through my study how far an individual Indian women working in professional sector with higher educational level and good economic status have authority to make decision regarding household matters in the family.

\section{Research Objective}

- To examine the degree of participation of professional Indian women in the decision making power in the family on the aspect of domestic chores.

\section{Review of Related Literature}

The participation of women in every level of decision-making process is important to achieve equal rights and opportunities as well as for the benefit and well-being of the family. Generally, women already start to involve in various profession outside their homes and they are not bound to the domestic sphere only nowadays. The traditional and primary role of women as a home maker has developed into dual role of working women and home maker simultaneously. Education attainment and financial independence are two important indicators that helped women to have wider outlook and exposure as well as play a role to change their mind set and attitudes (Chouhan, Choundhary and Swarnakar, 2016).

In this modern era, the number of women entering the work force is increasing and this facilitate in changing the earning structure and economic status of the family (Patil, 2016). Moreover, Sarmah (2015) states that changes can be noticed in the mentality of the society regarding the position of women inside and outside of the home. Besides, transformation also can be seen in the traditional belief of male chauvinistic role as the main decision maker in the family. Moreover, women already begin to participate in decision-making process in the family in various matters equally with their husband concerning the well-being of the family (Sarmah, 2015).

Moreover, Acharya, Bell, Simkhada, Van Teijlingen and Regmi (2010) provide that employment status of women have positive impact on their decision-making power in household management. Besides, another study also supported that women's earnings improves the participation in decision-making because women able to prove their position at home and in the society by contributing to the household expenses (Kaur, Singh, Sandhu and Kaur, 2018). 
However, it can be noted that conflict related to work-life balance for women is occurring in most of the societies because of the role overload and pressure faced by women to handle profession requirement, family and child care, relationship with their husband and household chores. Managing family become more difficult for working women because women have to take the primary responsibility to take care of their children and simultaneously need to balance their working life (Buddhapriya, 2009).

Moreover, women need social support to balance their family and working life in order to reduce the burden faced by them. Therefore, support from their husband is a crucial thing so that women able to manage their multiple roles. In Indian society, although the husband do not mind when their wives are working outside the home but there is less support when it comes to sharing of household chores. Even though the reformation and modernization have helped women to participate in the work force and involve in different professions but the social norms and traditional belief still influencing the society especially related to women's gender role. Thus, sharing of domestic work equally between husband and wife still an issue due to higher expectation imposed on women (Reddy, Vranda, Ahmed, Nirmala and Siddaramu, 2010). Therefore, this study aims to examine the participation of professional Indian women in decision-making power in family on domestic aspects.

\section{Methodology}

Qualitative research has been used in this study as it focuses on the importance of women's personal stories and experiences (Jackson, 1998). The view and opinion of women regarding topic involved can be revealed through qualitative research (Denzin and Lincoln, 2005). Thus, qualitative research with exploratory method can enable the researcher to find out the experiences of professional Indian women and the decision making authority that they have in the aspects related to domestic affairs.

Hesse-Biber (2007) mentioned that interview is the ideal approach to investigate the personal experiences of the women involved in the study. Following this, in-depth interview is an effective technique to understand family matters as it permit the women to share their stories (Webber and Byrd, 2010). Therefore, it is considered as appropriate instrument that enable women to speak out their experiences in family responsibilities. For qualitative study that adopt exploratory method, the selection of small number of respondents that less than twenty people are best done to build a close and friendly relationship so that the level of understanding on the topic of study is better (Crouch and McKenzie, 2006). So, fifteen respondents selected from population of Indian women lives in Selangor and Kuala Lumpur.

The criteria of the respondents chosen consist of married Indian women between 2840 years old, have children, education qualification of degree, master's degree and Ph.D, and working in different professional occupations. Purposive sampling method was used as it enable the researcher to select respondents based on the criteria fixed (Trochim, 2006). Moreover, snowball technique and friends networking approach were adopted to choose suitable respondents for the study. Selangor and Kuala Lumpur were chosen as the study areas because it is urbanization city with high population which provided job opportunities for people in many sectors (Department of Statistics Malaysia, 2010). The original names of the respondents were replaced with pseudonyms to secure the women's anonymity. The data obtained from the study were transcribed and translated before carrying out coding process to identify the crucial points and divide them into few sub-topics according to the objective of the study (Bryman, 2008). The findings and analysis discussed based on the themes involved in the study. 


\section{Results and Discussion \\ Domestic Work at Home}

Indian women's entry into the labour force has increased over the years but they are still facing the struggle to balance their work and family commitments no matter they are in which profession (Das and Žumbytè, 2017). This is because women's participation in work force does not mean they have been released from household chores.

\section{Contribution of Men in Household Chores}

Majority of the women mentioned that their husband do not mind in sharing the household work with them. Some of the women also revealed that how the sharing is done and they take turns to complete the work. They expressed that the support from their husband are very helpful and reduce their burden and stress. This shows that not in all Indian families the housework and child care placed on women alone but also exist equal participation of both husband and wife in household chores. For instance, one of the respondents said that:

"We divide the work, cleaning and washing me, ironing is husband, taking care of kids both, if major cleaning he will do, cooking both will do. Almost every day he will help in house chores since we got married because both of us working. He will do by himself without forcing".

Similarly, another respondent mentioned that:

"Cleaning he help every weekend, he will cook as well better than me. He is very helpful, he will just offer help and ask me to take rest".

It is also noted that more Indian men now are out of the mentality that domestic work at home should be done by women. Some of the respondents mentioned that they will make sure their husband do his part for the housework although he had been brought up in a different kind of family practice. This shows that women nowadays are also able to train their husband to participate in household chores although he does not have the experience of doing it before marriage. So, majority of the women receive assistance from their husband and they share the household chores equally or do it together.

On the other hand, it can be seen that there are still Indian men who do not take part in sharing domestic duties at home and still expecting their wives to complete it although they are working too. Working Indian women have the thought that their husband should help to reduce their burden and even forced them to do it. However, it leads to arguments between them which might affect their marriage life. Therefore, women seem to be the one always to need to give in and sacrifice when comes to household responsibilities. They begin to accept the situation which will not change and continue being the one need to struggle with multiple roles. Thus, some of the Indian men still have the traditional mindset that it is women's duty to complete the household chores. For example, one the respondents mentioned that:

"Although my initial idea that husband and wife should share 50-50, but he was the youngest in the family. So I end up doing the most, occasionally he will help but it is not a regular pattern but I have accept it along the way. Sometimes I do ask him to do, on his own he will never do. Initially I forced him but it lead to unnecessary arguments, so I thought fine he is going to be like this, since marriage need at least one person to sacrifice, to give in, if both also logger heads, marriage will be difficult". 
Therefore, some of the women have to handle the housework alone since their husband do not provide any help although they have asked them to do so until it leads to arguments whereby finally they begin to accept the situation and do the works on their own. Another important point mentioned by the respondents is that Indian men have belief in the traditional gendered division of work due to the family background. When they are being raised in a family whereby women does all the housework and men were excused from that duty, this practice is being instilled in them since young age. This perception has caused the practice to be continued even after the marriage.

\section{Impact on Women's Freedom after Marriage}

The culture and traditional norms play an important role among Indian society which is also influenced by concept of patriarchy. According to Indian practice, a woman should view her husband as "God" and as a good wife she should worship him no matter how he behaves or what type of characteristics he possess (Tupe, 2014). Therefore, Indian women are often required to obey their husband and less encouraged to do anything without their husband's permission. So, this study would like to find out the freedom that women have to make decision regarding her personal things or any other matters after marriage.

\section{No Permission Required for Simple/Basic Things}

The respondents were asked whether they get permission from their husband before doing something. Based on the response, almost all the women said that they do not ask permission to do simple things but only inform their husband. They further explained that they will discuss and decide together for more serious or important issue. For instance, one respondent said:

"No, simple things no need to ask permission. I used to inform but serious things like buying property or financial issues we have to ask permission and discuss, same goes to him, he inform me. So, problem only arises when we don't inform each other".

They clarified that women should inform their husband, not getting permission if planning to go out with friends or intend to do any simple things. They felt that informing their husband is important to avoid problems, make husband feel better and they can also backup them in case of emergency. They further mentioned that permission is not necessary between the spouses as it feels like employer and employee relationship.

\section{Differences in Practice for Men and Women}

Some of the respondents mentioned that it is much easier for a man to go out with friends sometimes even without informing their wives but it is quite different for a woman. For example, another respondent explained that:

"Slightly I also have that issue, even though my husband gives me freedom, but there are differences when he wants to go out with his friends and when I want to go out with my friends. Same applies to some of the women that I have met, for them, when women are married, you have to control them, as a mother you have responsibility as you have kid at home, so should come back home fast, should not go here and there, do this and that. Not necessary to ask permission for all the aspects, only important things. I will just inform so that he knows where I am in case of emergency". 
Therefore, the practice differs for men and women if plan to go outing with friends because women have more commitments to settle at home compared to men. When the women want to go out to spend time with friends, she definitely need to inform her husband and arrange things first before go. Sometimes, their husband even think twice before letting them go. This creates some dissatisfaction among women but they have to give and take when comes to family. Based on the experiences of some Indian women, it can also be noted that some husband are still dominating and controlling their wives in certain Indian families on what their wives should do or should not do.

Overall, it can be seen that most of the respondents do not ask permission from their husband to do any basic or fundamental things and they have freedom in it but they make sure to inform them so that their husband are aware of it. However, they always discuss and come out with a decision together with their husband if it is a major issue or anything related to the well-being of the family.

\section{The Participation of Women in the Decision-Making in Household Matters}

Among Indian society, the power to make decision always placed on the male family elders that recognized as head of family. However, the barrier for Indian women to participate in decision-making process in the family slowly changes as time goes by. Women's decisionmaking power also depends on multiple factors such as socio-cultural practice, education, employment, and type of family (Maral and Kumar, 2017).

Based on the interview, it is found that all the respondents are given equal participation in the decision-making process in their respective families. They also state that their husband respect their decision-making power and always consult them or ask their opinion before making the final decision. For instance, one of the respondents said that:

"50-50, usually we discuss and then come to a conclusion, most of the time I will be the final decision maker. If things that I am not familiar or don't have knowledge in it then he will be the decision maker. If not happy with the decision made, I will voice out. Mostly I win in the argument and I give in more also".

It is noticed that Indian women are getting importance in the family when decision is made and they are also able to participate equally regardless of gender. Moreover, they are voicing out their dissatisfaction if they are not happy with the decision made by their husband or when their husband do not consult them first. They further clarified that sometimes it leads to argument and either one of them will give in depends on their justification regarding the issue involved or who have more knowledge in the matter discussed. However, they ensure that the final decision made is satisfied for both but sometimes adjustment is needed when the decision is not favourable to either one of the partner.

Moreover, the key point that can be noticed here is final decision-maker in the family highly depends on the issues involved. According to the respondents, in the process of decision-making, sometimes argument occurs and either one of them have to give in or compromise and who wins the argument also depends on the matter concerned. Thus, in certain families husband in charge of family expenses but they are families whereby women are the decision-maker for financial aspect. It is also noted that in some families, the husband and wife are equally involved in decision-making regarding financial commitments.

Furthermore, majority of the women are being joint decision-makers with their husband since they are also contributing for the expenses of the family. So, they are also able 
to provide their stand when any decision is made regarding financial aspect in the family (Sharma and Kota, 2019). Moreover, majority of the respondents mentioned that they are the final decision-maker regarding children affairs. Women mentioned that they will consult and asked the opinion of their husband but they will take the final decision. The women also told that their husband felt that they can make better decision related to children matters compared to them.

\section{Conclusion}

Majority of the women interviewed said that their husband is participating equally in doing domestic work at home. They take turns to complete the work and the women also make sure that they train their husband to participate in household chores although no experience of doing it before. However, there are also women who facing difficulties when their husband is not willing to contribute to the household management. They had no choice but to give in and accept the situation whereby some of them pointed out that the main reason for this scenario to happen is due to family practice and upbringing. Besides that, the women interviewed further explained that they practiced the concept of informing rather than asking permission for simple or basic things. However, they felt that the freedom for men and women is different because men can go out to catch up with friends more easily and even without informing their wives. The situation is different for women who have to settle all the necessary things first then inform their husband before finally go out. Another important point that needs to be highlighted here is that almost all the women able to participate equally in the decision-making process in the family regarding household matters. This is because their husband respects their decision-making power and always consults with them first before making the final decision. In addition, women also shared their personal experience of voicing out their dissatisfaction when they are not happy with the decision made. Sometimes it lead to arguments but they usually solved it based on the justification given by each of them so that they able to come to a conclusion of the best decision to be taken for the benefit of the family.

\section{Contribution of Research}

This study contributes to the literature on Indian women as it gives an insight and understanding about the current trend of professional Indian women's participation in the decision-making on the aspect of domestic sphere. Thus, the findings from this study will be beneficial and become a source of reference for any future studies related to Indian women. Besides, this study will be able to create awareness among the Indian women regarding the changes in the traditional practice in domestic sphere and encourage them to participate actively in the process of decision-making in the family.

\section{References}

Acharya, D. R., Bell, J. S., Simkhada, P., Van Teijlingen, E. R., \& Regmi, P. R. (2010). Women's autonomy in household decision-making: a demographic study in Nepal. Reproductive health, 7(1), 1-12.

Bryman, A. (2008). Social research methods. Oxford university press.

Buddhapriya, S. (2009). Work-family challenges and their impact on career decisions: A study of Indian women professionals. Vikalpa, 34(1), 31-46.

Chouhan, S., Choundhary, S., \& Swarnakar, V. K. (2016). Study on decision making process with reference to risk taking behaviour of rural woman vegetables growers in Jobat 
Block of Alirajpur District, Madhya Pradesh, India. International Journal of Science and Reserch (IJRS), 5(2), 91-94.

Crouch, M., \& McKenzie, H. (2006). The logic of small samples in interview-based qualitative research. Social science information, 45(4), 483-499.

Das, M. B., \& Žumbytè, I. (2017). The motherhood penalty and female employment in urban India. The World Bank.

Denzin, N. K., \& Lincoln, Y. S. (2005). Introduction: The discipline and practice of qualitative research.

Department of Statistics Malaysia (2010).

Hesse-Biber, S. N. (2007). The practice of feminist in-depth interviewing. Feminist research practice: A primer, 111148, 111-138.

Jackson, E. (2010). Women's role in maintaining and/or resisting patriarchy. In Feminism and Contemporary Indian Women's Writing (pp. 111-140). Palgrave Macmillan, London.

Jackson, W. (1998). Methods: Doing social research. Scarborough, Ontario: Prentice-Hall Canada Inc.

Kaur, R., Singh, B., Sandhu, L. K., \& Kaur, G. (2018). Dimensions of women autonomy in household decision making in rural Punjab. OIDA International Journal of Sustainable Development, 11(01), 11-40.

Maral, P., \& Kumar, V. (2017). Family structure and decision-making power among working and non-working women. International Journal of Social Sciences Review, 5(4), 574580.

Namdeo, R. P. (2017). Impact of education on decision-making ability of women. Educational Quest, 8, 431.

Neeru, S., Muzamil, J., Farhat, M., \& Iffat, G. (2014). Decision making power among women in joint and nuclear families. Asian Journal of Home Science, 9(1), 29-34.

Patil, M. (2016). Stress level of working and non-working women. The International Journal of Indian Psychology, 3(4), 31-37.

Reddy, N. K., Vranda, M. N., Ahmed, A., Nirmala, B. P., \& Siddaramu, B. (2010). Work-life balance among married women employees. Indian Journal of Psychological Medicine, 32(2), 112-118.

Sarmah, B. (2015). The role of women in decision makining in the family with the special reference to Kamrup District (ASSAM). International Journal of Engineering Sciences and Technology, 4(6), 440-444.

Sharma, M., \& Kota, H. B. (2019). The role of working women in investment decision making in the family in India. Australasian Accounting, Business and Finance Journal, 13(3), 91-110.

Sultana, A. M. (2011). Factors effect on women autonomy and decision-making power within the household in rural communities. Journal of Applied Sciences Research, 7(1), 18-22.

Trochim, W. M. (2006). Nonprobability sampling. Research methods knowledge base, 1(1), 1-10.

Tupe, N. B. (2014). Triangular attitude of patriarchy: A major issue of lifelong learning among women in India. Business and Management Research, 3(4), 11-25.

Webber, G. R., \& Byrd, S. E. (2010).Conducting in-depth interviews. Yumi, S. \&Beaudry, S. (2007). Resource mobilization. World Bank small grants Program Social development department. 